ISSN 0103-8478

\title{
Estimates of (co)variance components and genetic parameters for growth traits in Suffolk lambs
}

\section{Estimativas de componentes de (co)variância e parâmetros genéticos para características de crescimento em cordeiros Suffolk}

\author{
Priscilla Regina Tamioso ${ }^{\mathrm{I}}$ Jaime Luiz Alberti Filho ${ }^{\mathrm{II}}$ Laila Talarico Dias ${ }^{\mathrm{III}}$ \\ Rodrigo de Almeida Teixeira ${ }^{\text {III }}$
}

\section{ABSTRACT}

The study aimed to estimate the components of (co) variance and heritability for weights at birth (BW), weaning (WW) and 180 days of age (W180), as well as the average daily gains from birth to weaning (ADG1), birth to 180 days of age (ADG2) and weaning to 180 days of age (ADG3) in Suffolk sheep. Thus, three different single-trait animal models were fitted, considering the direct additive genetic effect (Model 1), the direct additive genetic and maternal permanent environmental effects (Model 2), and in Model 3, in addition to those in Model 2, the maternal additive genetic effect was included. After comparing models through the likelihood ratio test (LRT), model 3 was chosen as the most appropriate to estimate heritability for $B W, W W$ and ADG1. Model 2 was considered as the best to estimate the coefficient of heritability for W180 and ADG2, and model 1 for ADG3. Direct heritability estimates were inflated when maternal effects were ignored. According to the most suitable models, the heritability estimates for $B W, W W, W 180, A D G 1, A D G 2$ and $A D G 3$ were $0.06,0.08,0.09,0.07,0.08$ and 0.07 , respectively, indicating low possibility of genetic gain through individual selection. The results show the importance of including maternal effects in the models to properly estimate genetic parameters even at post-weaning ages.

Key words: average daily weight gain, body weight, heritability, maternal effects, Suffolk.

\section{RESUMO}

Objetivou-se estimar os componentes de (co) variância e herdabilidades para pesos ao nascer (PN), à desmama (PD) e aos 180 dias de idade (P180), além dos ganhos médios diários de peso do nascimento à desmama $\left(G M D_{N-D}\right)$, do nascimento aos 180 dias de idade $\left(G M D_{N-180}\right)$ e da desmama aos 180 dias de idade $\left(G M D_{D-180}\right)$, de ovinos da raça Suffolk. Para isso, utilizaram-se três modelos diferentes, considerando o efeito genético aditivo direto (Modelo 1), os efeitos genético direto e de ambiente permanente materno (Modelo 2) e, no Modelo 3, além daqueles contemplados no Modelo 2, foi incluído o efeito genético materno. Após comparar os modelos por meio do teste de razão de verossimilhança (LRT), observou-se que o 3 foi o mais adequado para estimar a herdabilidade para $P N, P D$ e $G M D_{N-D}$. Já o modelo 2 foi considerado como o melhor para estimar o coeficiente de herdabilidade para $P 180$ e $G M D_{\mathrm{N}-180}$, o modelo 1, para $G M D_{D-180^{-}}$. As herdabilidades diretas foram inflacionadas quando os efeitos maternos foram ignorados. Os coeficientes de herdabilidade de baixa magnitude estimados para $P N, P D, P 180, G M D_{N-D}, G M D_{N-180}$ e $G M D_{D-180}$ foram iguais a 0,06, 0,08, 0,09, 0,07, 0,08 e 0,07, respectivamente, de acordo com os modelos mais apropriados, indicando que os ganhos genéticos obtidos por meio da seleção individual serão de pequena magnitude. Os resultados evidenciam a importância da inclusão dos efeitos maternos nos modelos para estimar adequadamente os parâmetros genéticos, mesmo após a desmama.

Palavras-chave: efeitos maternos, ganho médio diário, herdabilidade, peso corporal, Suffolk.

\section{INTRODUCTION}

Development of effective genetic evaluations and accurate selection of sires require the estimate of genetic parameters for economically important production traits, such as the heritability coefficients and genetic correlations between these traits. Through the knowledge of these parameters, it is be possible to predict whether a given trait will respond to individual selection and, thus, the inclusion of it as a selection criterion.

Genetic parameters for growth traits in sheep are widely described in the literature, as well as the comparisons among genetic models. Growth

\footnotetext{
IPrograma de Pós-graduação em Ciências Veterinárias (PPGCV), Departamento de Zootecnia, Curso de Zootecnia, Universidade Federal do Paraná (UFPR), 80035-050, Curitiba, PR, Brasil. E-mail: priscillatamioso@gmail.com. Autor para correspondência.

${ }^{\text {IIC }}$ urso de Zootecnia, UFPR, Curitiba, PR, Brasil.

IIIDepartamento de Zootecnia, UFPR, Curitiba, PR, Brasil. Received 02.05.13 Approved 07.11.13 Returned by the author 10.07.13 CR-2013-0158.R2
} 
traits are relevant for lambs production systems and, in order to obtain genetic gain, it is necessary to understand the direct and maternal components that influence these traits, as well as to determine the contribution of each effect on the animal performance. Therefore, it is necessary to partition the direct, permanent environmental and maternal genetic effects.

Studies with different sheep breeds have shown that both direct and maternal genetic effects act on lambs' growth performance (MARÍA et al., 1993; SNYMAN et al., 1995; MANDAL et al., 2006a, b; PRINCE et al., 2010), thus, to achieve greater genetic progress in selection programs and increased accuracy in estimates, both components need to be considered in genetic models (MEYER, 1992).

The Suffolk breed, which has great economic importance in Southern Brazil, is wellknown for its efficiency in meat production, precocity and disease resistance (ALZUGARAY \& ALZUGARAY, 1986), important factors for production in extensive systems, the most commonly established in the country. However there are few reports on models comparison to estimate genetic parameters for growth traits at pre-and post-weaning ages in this breed.

The aim of this study was to identify the most suitable model to accurately estimate the genetic parameters for growth traits at pre- and post-weaning ages in Suffolk sheep.

\section{MATERIAL AND METHODS}

Data were collected from a commercial flock (Sementes e Cabanha Butiá Ltda.), located in the state of Rio Grande do Sul, Southern Brazil, and were granted by the company Gensys Consultores Associados Ltda. Body weight records from 4314 Suffolk lambs born between 1992 and 2007, offspring of 1124 ewes and 106 rams, were analyzed, being 1334, 2699 and 266 single-, twin- and triplet-born lambs, respectively.

For the statistical analysis, three data sets with records on weight at birth (BW), weaning (WW) and 180 days of age (W180), as well as the average daily gain from birth to weaning (ADG1), birth to 180 days of age (ADG2) and weaning to 180 days of age (ADG3) were generated. Animals without information about body weight, management group, born to dams aged $>9$ years old and contemporary groups (formed by the variables year of birth, sex and management group at weaning) with less than 10 animals were excluded.
Regarding the BW, the fixed effects of year of birth and sex, and, as covariates, the linear effect of type of lambing (single, twin and triple birth) and the linear and quadratic effects of age of dam at lambing (years) were considered. For WW and W180 the contemporary group was included as a fixed effect and, as covariates, the linear effect of type of lambing (single, double and triple birth) and the linear and quadratic effects of age of dam at lambing (years) and age of the animal at measurement (days). It is important to notice that, for W180, the management group at weaning was considered, since at this age all the animals belonged to the same group. After edition, the BW, WW and W180 data set consisted of 4299, 3002 and 2925 animals, respectively.

Likewise, for ADG1, ADG2 and ADG3 the model included, as fixed, the contemporary group and, as covariates, the linear and quadratic effects of age of the animal at weaning or the age of the animal at 180 days old, in addition to the linear effect of type of lambing (single, double or triple birth) and the linear and quadratic effects of age of dam at lambing, in years, except the average daily gain from birth to 180 days of age (ADG2). The final sets accounted for 3201, 2927 and 2922 observations for ADG1, ADG2 and ADG3, respectively.

Univariate analyses were performed for the three different animal models, considering various combinations of maternal genetic and permanent environmental effects. The general models for the genetic parameters estimates can be described in matrix formas:

(1) $Y=X \beta+Z a+e$

(2) $Y=X \beta+Z a+W p+e$

(3) $Y=X \beta+Z a+M m+W p+e$, with $\operatorname{cov}(a, m)=0$

Where $\mathrm{Y}$ is the vector of observations (BW, WW, W180, ADG1, ADG2 or ADG3); $\beta$, a, $\mathrm{m}, \mathrm{p}$ are the vectors of fixed, direct additive genetic effects, maternal additive genetic effects and maternal permanent environmental effects, respectively; X, $\mathrm{Z}, \mathrm{M}, \mathrm{W}$ are the incidence matrices related to the respective effects; e is the vector of random residuals.

Variance components were obtained by the derivative-free restricted maximum likelihood, using the software MTDFREML (BOLDMAN et al., 1995), being the selection of the appropriate model for each trait performed through the Log-likelihood ratio test (LRT), which compares the increased likelihood function $(-\log 2 \mathrm{~L})$, caused by adding a parameter to a chi-square distribution with degrees of freedom and probability of error of $5 \%(\mathrm{P}<0.05)$ (HOGG \& CRAIG, 1995). 


\section{RESULTS AND DISCUSSION}

Table 1 lists the comparison between the three models by the likelihood ratio test in order to estimate the heritability for body weight and average daily gain. From table 1, it is observed the importance of the maternal effects to estimate genetic parameters for growth traits, since the non-inclusion of these effects overestimated the heritability coefficients, as highlighted in several studies with different sheep breeds (MANIATIS \& POLLOTT, 2002; EKIZ et al., 2004; MANDAL et al., 2006a; GHAFOURI-KESBI et al., 2011).

The definition of the statistical model to determine genetic parameters is essential, once the correct inclusion of the fixed and random effects indicates more accurate estimates for the traits of economic interest. Through the LRT, it is possible to notice that, for weight at birth and weaning, Model 3 was the most appropriate. Similarly, SNYMAN et al. (1995) and ZAMANI \& MOHAMMADI (2008), working with Afrino and Mehraban sheep, respectively, reported that the best model for BW included these effects, but not the covariances between them. However, for weight at 180 days of age, the significant comparison between Models 1 and 2 suggests that the maternal permanent environmental influence should be considered for the analysis of body weight even at post-weaning ages. MANDAL et al. (2006b) and GOWANE et al. (2010), in Muzaffarnagari and Bharat Merino sheep, respectively, showed that the maternal permanent environmental effect after weaning may have acted as a carry-over effect of maternal influences.

On the contrary, for ADG1, ADG2 and ADG3 the LRT indicated Models 3, 2 and 1, respectively, as the most suitable. RASHIDI et al. (2008) fitted different models to evaluate average daily gain from birth to weaning of Kermani sheep and reported that the best model included the direct additive genetic and maternal permanent environmental effects. Moreover, PRAKASH et al. (2012), in Mapura sheep of India, found that the best model for ADG1 and ADG3 included the direct genetic and permanent environmental effects, and for ADG2, it considered only the direct additive effect.

Table 1 - Comparison between the three proposed models and estimates of direct heritability $\left(\mathrm{h}_{\mathrm{d}}^{2}\right.$ ), with respective standard errors (se) for birth weight (BW), weaning weight (WW), weight at 180 days of age (W180), average daily gain from birth to weaning (ADG1), birth to 180 days of age (ADG2) and weaning to 180 days of age (ADG3), in Suffolk lambs

\begin{tabular}{|c|c|c|c|c|c|}
\hline Trait & Models & $-2 \log \mathrm{L}$ & Model comparisons & LRT & $\mathrm{h}_{\mathrm{d}}^{2} \pm \mathrm{se}$ \\
\hline \multirow{3}{*}{ BW } & 1 & 5407.05 & $(2-1)$ & $318.34^{* *}$ & $0.38 \pm 0.03$ \\
\hline & 2 & 5088.71 & $(3-2)$ & $37.57^{* *}$ & $0.06 \pm 0.02$ \\
\hline & 3 & 5051.14 & $(3-1)$ & $355.91^{* *}$ & $0.06 \pm 0.02$ \\
\hline \multirow{3}{*}{ WW } & 1 & 13598.95 & $(2-1)$ & $36.94^{* *}$ & $0.16 \pm 0.03$ \\
\hline & 2 & 13562.01 & $(3-2)$ & $9.72^{* *}$ & $0.07 \pm 0.03$ \\
\hline & 3 & 13552.29 & $(3-1)$ & $46.66^{* *}$ & $0.08 \pm 0.04$ \\
\hline \multirow{3}{*}{ W180 } & 1 & 14774.32 & $(2-1)$ & $20.11^{* *}$ & $0.15 \pm 0.03$ \\
\hline & 2 & 14754.21 & $(3-2)$ & $2.92^{\mathrm{ns}}$ & $0.09 \pm 0.03$ \\
\hline & 3 & 14751.29 & $(3-1)$ & $23.03^{* *}$ & $0.07 \pm 0.03$ \\
\hline \multirow{3}{*}{ ADG1 } & 1 & 14928.52 & $(2-1)$ & $21.64^{* *}$ & $0.15 \pm 0.03$ \\
\hline & 2 & 14906.88 & $(3-2)$ & $8.46^{* *}$ & $0.09 \pm 0.03$ \\
\hline & 3 & 14898.42 & $(3-1)$ & $30.10^{* *}$ & $0.07 \pm 0.03$ \\
\hline \multirow{3}{*}{ ADG2 } & 1 & 14750.51 & $(2-1)$ & $16.40^{* *}$ & $0.13 \pm 0.03$ \\
\hline & 2 & 14734.09 & $(3-2)$ & $1.43^{\mathrm{ns}}$ & $0.08 \pm 0.03$ \\
\hline & 3 & 14732.66 & $(3-1)$ & $17.85^{* *}$ & $0.07 \pm 0.03$ \\
\hline \multirow{3}{*}{ ADG3 } & 1 & 12816.49 & $(2-1)$ & $3.35^{\mathrm{ns}}$ & $0.07 \pm 0.02$ \\
\hline & 2 & 12813.14 & $(3-2)$ & $0.0^{\mathrm{ns}}$ & $0.06 \pm 0.02$ \\
\hline & 3 & 12813.14 & $(3-1)$ & $3.35^{\mathrm{ns}}$ & $0.06 \pm 0.03$ \\
\hline
\end{tabular}

$* * \mathrm{P}<0.01 ;{ }^{\mathrm{ns}}$ non significant; -2log L: log-likelihood function; LRT: likelihood ratio test. 
Table 2 - Components of (co)variance and estimates of heritability for birth weight (BW), weaning weight (WW), weight at 180 days of age (W180), average daily gain from birth to weaning (ADG1), birth to 180 days of age (ADG2) and weaning to 180 days of age (ADG3), fitting the most appropriate model, in Suffolk lambs

\begin{tabular}{|c|c|c|c|c|c|c|}
\hline $\begin{array}{l}\text { Components of } \\
\text { (co)variance }\end{array}$ & BW (Model 3) & WW (Model 3) & W180(Model 2) & ADG1(Model 3) & ADG2 (Model 2) & ADG3 (Model 1) \\
\hline$\sigma_{a}^{2}$ & 0.07 & 1.96 & 4.26 & 2.67 & 4.74 & 2.36 \\
\hline$\sigma_{c}^{2}$ & 0.23 & 2.29 & 3.73 & 1.41 & 4.14 & - \\
\hline$\sigma_{\mathrm{m}}^{2}$ & 0.24 & 1.93 & 1.54 & 2.11 & - & - \\
\hline$\sigma_{p}^{2}$ & 1.41 & 35.35 & 58.54 & 39.56 & 57.58 & 31.60 \\
\hline $\mathrm{h}_{\mathrm{d}}^{2} \pm \mathrm{se}$ & $0.06 \pm 0.02$ & $0.08 \pm 0.04$ & $0.09 \pm 0.03$ & $0.07 \pm 0.03$ & $0.08 \pm 0.03$ & $0.07 \pm 0.02$ \\
\hline $\mathrm{h}_{\mathrm{m}}^{2} \pm \mathrm{se}$ & $0.17 \pm 0.04$ & $0.05 \pm 0.03$ & - & $0.05 \pm 0.02$ & - & - \\
\hline
\end{tabular}

$\sigma_{\mathrm{a}}^{2}$ : direct additive genetic variance; $\sigma_{\mathrm{c}}^{2}$ : maternal permanent environmental variance; $\sigma_{\mathrm{m}}^{2}$ : maternal additive genetic variance; $\sigma_{\mathrm{p} \text { : }}^{2}$ phenotypic variance, $\mathrm{h}_{\mathrm{d}}^{2}$ : direct heritability; $\mathrm{h}_{\mathrm{m}}^{2}$ : maternal heritability; se: standard error.

The components of (co)variance after choosing the most appropriate models for body weight and average daily gain during the studied periods are given in table 2 . As the models indicated by the LRT, the heritability estimates were $0.06,0.08$ and 0.09 for BW, WW and W180, respectively, low in magnitude, but similar to the results in the literature (MARÍA et al., 1993; EKIZ et al. 2004; GOWANE et al., 2010). In studies with Suffolk sheep, MAXA et al. (2007) found moderate heritability estimate $(0.19 \pm 0.04)$ for birth weight, using a model which included the maternal genetic effect. Additionally, NOTTER (1998) estimated low direct heritability (0.14 to 0.21 ) for weaning weight, in univariate analyses, considering different weaning ages, as well as RAO \& NOTTER (2000) (0.19).

Similarly, the direct heritability estimates for weight gains from birth to weaning, birth to 180 days of age and weaning to 180 days of age were low in magnitude, ranging from 0.07 (ADG1 and ADG3) to 0.08 (ADG2). In relation to ADG1, heritability values reported in the literature range from 0.11 to 0.22 (ABEGAZ et al., 2005; ESKANDARINASAB et al., 2010; GHAFOURI-KESBI et al., 2011), higher than those found in this paper. For ADG2, the estimate was in range with findings of ESKANDARINASAB et al. (2010) (0.07) in Afsari sheep, and lower than found by GHAFOURI-KESBI et al. (2011) (0.15), in Zandi sheep. Finally, for ADG3, the low coefficients are similar to those estimated by EKIZ (2005) (0.08), evaluating Turkish Merino lambs and GHAFOURIKESBI et al. (2011) (0.09).

The maternal heritability estimates $\left(h^{2} \mathrm{~m}\right)$ for BW and WW from Model 3 presented moderate and low magnitudes, equal to $0.17 \pm 0.04$ e $0.05 \pm 0.03$, respectively. For BW, using the same model, the obtained coefficient was in accordance to reports by ZAMANI \& MOHAMMADI (2008) (0.20) and higher than those observed by LIGDA et al. (2000) (0.13), MATIKA et al. (2003) (0.12), EKIZ et al. (2004) (0.10) and PRINCE et al. (2010) (0.08). For Suffolk lambs, MANIATI \& POLLOTT (2002) estimated a high maternal heritability coefficient equal to $0.50 \pm 0.06$, considering the same model. However, for WW, the values estimated by LIGDA et al. (2000) (0.05), MATIKA et al. (2003) (0.06) and ZAMANI \& MOHAMMADI (2008) (0.08) were similar to the results presented. The lower heritability estimates for WW, when compared to $\mathrm{BW}$, could be probably explained by the fact that maternal effects have significant influence on the early growth of mammals, decreasing with age (ROBISON, 1981).

Maternal heritability estimate for ADG1 was also low (0.05 \pm 0.02$)$. Likewise, PRINCE et al. (2010), using similar animal model, published report of $0.00 \pm 0.00$ in Avikalin sheep and GHAFOURIKESBI et al. (2011) obtained $\mathrm{h}^{2}$ equal to $0.03 \pm 0.01$. The low estimate indicates difficulty in improving maternal ability for average daily weight gain from birth to weaning and reinforces the fact that the early growth is also determined by maternal effects.

\section{CONCLUSION}

The inclusion of maternal effects is necessary for the accurate estimation of genetic parameters for growth traits, even at post-weaning ages. Except for the average daily gain from weaning to 180 days of age, the addition of the direct genetic effect may be sufficient to estimate genetic parameters.

The heritability estimates indicated low possibility of direct response for the growth traits, 
however they may be used as selection criteria, due to their economic importance for meat production.

\section{REFERENCES}

ABEGAZ, S. et al. Model comparisons and genetic and environmental parameter estimates of growth and the Kleiber ratio in Horro sheep. South African Journal of Animal Science, v.35, p.30-40, 2005. Available from: <http://www.ajol.info/index.php/ sajas/article/view/4046/11889.> Accessed: Aug 15, 2012.

ALZUGARAY, D.; ALZUGARAY, C. Aprenda a criar ovelhas. São Paulo, SP: Editora TRÊS, 1986. 96p.

BAHREINI BEHZADI, M.R. et al. Estimates of genetic parameters for growth traits in Kermani sheep. Journal of Animal Breeding and Genetics, v.124, p.296-301, 2007. Available from: <http:// onlinelibrary.wiley.com/doi/10.1111/j.1439-0388.2007.00672.x/ full>. Accessed: Aug 15, 2012. doi: 10.1111/j.14390388.2007.00672.x.

BOLDMAN, K.G. et al. A manual for use for MTDFREML: a set of programs to obtain estimates of variance and covariance. Lincoln: Department of Agriculture/Agricultural Research Service, 1995. 120p.

EKIZ, B. Estimates of maternal effects for pre- and post-weaning daily gain in Turkish Merino lambs. Turkish Journal of Veterinary and Animal Sciences, v.29, p.399-407, 2005. Available from: <http:// mistug.tubitak.gov.tr/bdyim/abs.php?dergi=vet\&rak=0309-23>. Accessed: Aug 06, 2012.

EKIZ, B. et al. Estimates of genetic parameters for direct and maternal effects with six different models on birth and weaning weights of Turkish Merino lambs. Journal of Veterinary and Animal Sciences, v.28, p.383-389, 2004. Available from: <http:// journals.tubitak.gov.tr/veterinary/issues/vet-04-28-2/vet-28-2-220211-31.pdf>. Accessed: Sept. 03, 2012.

ESKANDARINASAB, M. et al. Different models for evaluation of growth traits and Kleiber ration in an experimental flock of Iranian fat-tailed Afshari sheep. Journal of Animal Breeding and Genetics, v.127, p.26-33, 2010. Available from: <http:// onlinelibrary.wiley.com/doi/10.1111/j.1439-0388.2008.00789.x/ full >. Accessed: Sept. 03, 2012. doi: 10.1111/j.14390388.2008.00789.x.

GHAFOURI-KESBI, F. et al. Genetic analysis of growth rate and Kleiber ratio in Zandi sheep. Tropical Animal Health and Production, v.43, p.1153-1159, 2011. Available from: $<$ http://link. springer.com/article/10.1007\%2Fs11250-011-9816-2?LI=true. $>$ Accessed: Aug. 15, 2012. doi: 10.1007/s11250-011-9816-2.

GOWANE, G.R. et al. Estimates of (co)variance components and genetic parameters for body weights and first greasy fleece weight in Malpura sheep. Livestock Science, v.131, p.94-101, 2010. Available from: <http://www.livestockscience.com/article/ S1871-1413(10)00114-9/fulltext>. Accessed: Sept. 03, 2012. doi: 10.1016/j.livsci.2010.03.006.

HOGG, R.V.; CRAIG, A.T. Introduction to mathematical statistics. 5.ed. New Jersey: Prentice Hall, 1995. 564p.

LIGDA, C. et al. Investigation of direct and maternal genetic effects on birth and weaning weight of Chios lambs. Livestock
Production Science, v.67, p.75-80, 2000. Available from: $<\mathrm{http}: / /$ dx.doi.org/10.1016/S0301-6226(00)00185-8>. Accessed: Sept. 30, 2012. doi: 10.1016/S0301-6226(00)00185-8.

MANDAL, A. et al. Estimation of direct and maternal (co)variance components for pre- weaning growth traits in Muzaffarnagari sheep. Livestock Science, v.99, p.79-89, 2006a. Available from: $<$ http://dx.doi.org/10.1016/j.livprodsci.2005.06.001>. Accessed: Aug. 06, 2012. doi: 10.1016/j.livprodsci.2005.06.001.

MANDAL, A. et al. Genetic parameters for direct and maternal effects on body weights of Muzaffarnagri sheep. Animal Science, v.82, p.133-140, 2006b. Available from: <http://journals. cambridge.org/abstract S1357729806000178>. Accessed: Aug. 06, 2012. doi: 10.1079/ASC200531.

MANIATIS, N.; POLLOTT, G.E. Maternal effects on weight and ultrasonically measured traits of lambs in a small closed Suffolk flock. Small Ruminant Research, v.45, p.235-246, 2002. Available from: $<$ http://dx.doi.org/10.1016/S0921-4488(02)00114-1>. Accessed: Sept. 30, 2012. doi: 10.1016/S0921-4488(02)00114-1.

MARÍA, G.A. et al. Estimates of variances due to direct and maternal effects for growth traits of Romanov sheep. Journal of Animal Science, v.71, p.845-849, 1993. Available from: $<\mathrm{http}$ ://www.journalofanimalscience.org/content/71/4/845.short>. Accessed: Aug. 06, 2012.

MATIKA, O. et al. Genetic parameter estimates in Sabi sheep. Livestock Production Science, v.79, p.17-28, 2003. Available from: $<$ http://dx.doi.org/10.1016/S0301-6226(02)00129-X>. Accessed: Sept 30, 2012. doi: 10.1016/S0301-6226(02)00129-X

MAXA, J. et al. Genetic parameters for growth traits and litter size in Danish Texel, Shropshire, Oxford Down and Suffolk. Small Ruminant Research, v.68, p.312-317, 2007. Available from: $<$ http://dx.doi.org/10.1016/j.smallrumres.2005.12.001>. Accessed: Aug. 06, 2012. doi: 10.1016/j.smallrumres.2005.12.001.

MEYER, K. Variance components due to direct and maternal effects for growth traits of Australian beef cattle. Livestock Production Science, v.31, p.179-204, 1992. Available from: $<$ http://dx.doi.org/10.1016/0301-6226(92)90017-X.> Accessed: Sept. 03, 2012. doi: 10.1016/0301-6226(92)90017-X.

NOTTER, D.R. Genetic parameters for growth traits in Suffolk and Polypay sheep. Livestock Production Science, v.55, p.205213, 1998. Available from: <http://dx.doi.org/10.1016/S03016226(98)00141-9>. Accessed: Aug. 15, 2012. doi: 10.1016/S03016226(98)00141-9.

PRAKASH, V. et al. The estimation of (co)variance components and genetic parameters for growth traits and Kleiber ratios in Malpura sheep of India. Small Ruminant Research, v. 108, p. 54-58, 2012. Available from: <http://dx.doi.org/10.1016/j. smallrumres.2012.07.018>. Accessed: Aug 15, 2012. doi: 10.1016/j.smallrumres.2012.07.018

PRINCE, L.L.L. et al. Estimates of (co)variance components and genetic parameters for growth traits of Avikalin sheep. Tropical Animal Health and Production, v.42, p.10931101, 2010. Available from: <http://link.springer.com/ article/10.1007\%2Fs11250-010-9530-5?LI=true>. Accessed: Aug. 06, 2012. doi: 10.1007/s11250-010-9530-5.

RAO, S.; NOTTER, D.R. Genetic analysis of litter size in Targhee, Suffolk and Polypay sheep. Journal of Animal Science, v.78, p.2113- 
2120, 2000. Available from: <http://www.journalofanimalscience.org/ content/78/8/2113.short $>$. Accessed: Aug 22, 2012.

RASHIDI, A. et al. Genetic parameter estimates of pre-weaning growth traits in Kermani sheep. Small Ruminant Research, v.74, p.165-171, 2008. Available from: <http://dx.doi.org/10.1016/j. smallrumres.2007.06.004>. Accessed: Aug. 06, 2012. doi: 10.1016/j. smallrumres.2007.06.004.

ROBISON, O.W. The influence of maternal effects on the efficiency of selection: a review. Livestock Production Science, v.8, p.121-137, 1981. Available from: <http://dx.doi.org/10.1016/0301-6226(81)900166>. Accessed: Aug. 15, 2012. doi: 10.1016/0301-6226(81)90016-6.
SNYMAN, M.A. et al. Direct and maternal (co)variance components and heritability estimates for body weight at different ages and fleece traits in Afrino sheep. Livestock Production Science, v.44, p.229-235, 1995. Available from: <http://dx.doi. org/10.1016/0301-6226(95)00071-2.> Accessed: Aug 15, 2012. doi: 10.1016/0301-6226(95)00071-2.

ZAMANI, P.; MOHAMMADI, H. Comparison of different models for estimation of genetic parameters of early growth traits in the Mehraban sheep. Journal of Animal Breeding and Genetics, v.125, p.29-34, 2008. Available from: < http://onlinelibrary.wiley. com/doi/10.1111/j.1439-0388.2007.00676.x/pdf>. Accessed: Aug. 22, 2012. doi: 10.1111/j.1439-0388.2007.00676.x

Ciência Rural, v.43, n.12, dez, 2013. 